\title{
Markkinakuria kansalle
}

\author{
Anu Kantola (2002) \\ Markkinakuri ja \\ managerivalta. Poliitti- \\ nen hallinta Suomen \\ 1990-luvun talous- \\ kriisissä. 353 sivua. \\ LOKI-KIRJAT
}

\section{Suomen talouskriisistä} on kirjoitettu lukuisia teoksia, joissa on tarkasteltu siihen johtanutta kehitystä ja sen etenemistä. Suomen Akatemian talouskriisiä tutkineeseen tutkimusohjelmaan osallistunut Anu Kantola esittääkin väitöskirjassaan kysymyksen, miksi vielä yksi kirja kuluneesta aiheesta ja jo monta kertaa kalutusta aineistosta? Totta onkin, että lamatutkimuksiin perehtyneelle Kantolan tutkimuksessa käydään läpi samoja prosesseja ja episodeja, joita on moneen kertaan analysoitu. Kantolan vastaus on, että vaikka monissa tutkimuksissa kriisiä on kuvattu monipuolisesti, yksikään niistä ei ole keskittynyt kuvaamaan poliittisten päättäjien ajattelu- tapoja poliittisen hallinnan näkökulmasta. Vaikka tutkimus on julkaistu viestinnän opinnäytteenä, kykenen arvioimaan sitä vain omastani eli politiikan tutkimuksen näkökulmasta.

Kantola käyttää aineistonaan lamatutkimuksissa jo aiemminkin hyödynnettyä Sitran toimeksiannosta kerättyä haastatteluaineistoa, joka käsittää 71 elinkeinoelämän, virkamieskunnan, politiikan ja järjestöelämän talouspoliittisen vaikuttajan haastattelua. Haastattelut teki mm. säästöpankkien historiaa tutkinut Antti Kuusterä vuonna 1995. Voisi helposti kuvitella, että tutkijan tutkimustehtävän ratkaisemista helpottaa, jos hän voi turvautua valmiiseen aineistoon. Näin ei välttämättä ole. Tutkija on tällöin jonkun toisen tekemisen valintojen armoilla, eikä hänen oma ongelmanasettelunsa ole voinut ohjata aineiston muodostamista. Aineistokeskeisen lähestymistavan vaikeus näkyy Kantolan tutkimuksessakin sii- nä, että tutkimuksen kohteen, päättäjien tai poliittisen eliitin ja sen aineiston suhteeseen liittyy pientä kitkaa.

\section{Poliittisilla päättäjillä ja} poliittisilla eliiteillä Kantola tarkoittaa joukkoa, jolla on hallussaan yhteiskunnassa poliittiseen vallankäyttöön oikeuttavat asemat. Toisaalta hän viittaa eliitillä joukkoon, joka osallistuu poliittiseen vallankäyttöön tietyssä tilanteessa. Tarkoituksena on keskittyä siihen ydinjoukkoon, joka käytti poliittista valtaa nimenomaan Suomen 1990-luvun talouskriisissä. Kantola ei kuitenkaan selvästi eksplisoi sitä, mistä me tiedämme, ketkä tätä valtaa käyttivät talouskriisissä. Haastatteluaineistossa on ilmeisesti mukana henkilöitä, jotka tiukasti määritellen eivät ansaitse poliittisen päättäjän tai poliittiseen eliittiin kuuluvan titteliä. Erityisesti tämä koskee talouspolitiikan asiantuntija-asemassa olevia, joita aineistossa lienee joltinenkin määrä. Eliitin kokoonpanon arviointia vaikeuttaa se, että 
haastateltujen nimet tai edes virka-asemat eivät käy ilmi tutkimuksesta. Niiden julkistaminen tuskin olisi vaarantanut haastatelluille taattua anonymiteettia. Elegantti ratkaisu eliitin ja aineiston välisen suhteen täsmentämiseen olisi löytynyt esimerkiksi määrittelemällä eliitti useammasta vaikutusvallan kehästä koostuvaksi, jolloin analyysi kohdistuu sekä sisäkehään (formaaliset päätöksentekijät) että yhteen tai useampaan ulkokehään (asiantuntijavaltaa käyttävät ekonomistit). Itse asiassa tämän suuntainen malli näyttää olleenkin implisiittisesti Kantolan mielessä, kun hän on jakanut puhujat neljään ryhmään, rahapolitiikan, finanssipolitiikan ja tulopolitiikan päättäjiin sekä ekonomisteihin.

\section{Kantolan tutkimus-}

kysymys kuuluu: millainen poliittisen hallinnan tapa Suomen talouskriisistä rakentuu? Tämän hallinnan tavan rakentumista hän tutkii analysoimalla poliittisen eliitin puhetta. Keskeisiä kysymyksiä ovat: 1) millaisille käsitteellisille sanastoille hallinnan tapa rakentuu? 2) millaisilla strategioilla ja tekniikoilla hallinta oikeutetaan ja toteutetaan? 3) millainen eetos talouskriisin hallinnassa syntyy? 4) miten paikallinen historiallinen konteksti liittyy hallintaan? sekä 5) millainen on demokratian ihanteiden ja hallinnan käytäntöjen suhde?

\section{Poliittisen hallinnan}

tavan käsitteen Kantola johtaa Michel Foucault'n valtateoriasta ja sen lähinnä habermasilaisesta kritiikistä. Kantola ei keskity biovallan käsitteeseen (vaikkakin hyödyntää itseku- rin käsitettä), vaan painottaa Foucault'n myöhäiskaudellaan esiintuomaa yhteiskunnallisten rakenteiden ja instituutioiden merkitystä. Tutkijan tulkinnan mukaan vallan käsite ei ole Foucault'lle pelkästään kieleen sitoutunutta tai yksilöllistä, vaan hän pyrkii näkemään valtasuhteet yhteiskunnallisina kamppailuina, jotka kytkeytyvät yhteiskunnallisiin instituutioihin.

\section{Omaperäistä Kantolan}

tutkimusmenetelmässä on se, että siinä ei ole - sanoisinko yhteiskuntatieteen mainstreamista poiketen - sovellettu mitään erityistä diskurssianalyysin tai tekstianalyysin menetelmää, vaan aineistoa on eritelty teoreettisesta tutkimuskysymyksestä johdetun luokittelurungon mukaisesti. Joku voisi sanoa tällaista tutkimusmenetelmää "traditionaaliseksi", mutta itse pidän sitä ansiona. Tutkimusmenetelmä on väline, ei itseisarvo. Lähestymistapaansa Kantola kutsuu tulkinnaksi, ikään kuin verkon heittämiseksi tutun aineiston päälle, joka näyttää sen uudesta näkökulmasta. Tässä pyrkimyksessään Kantola onnistuu mainiosti.

\section{Kantolan mielestä}

Suomen 1990-luvun alun talouskriisi voidaan eliitin poliittisten kamppailujen valossa nähdä poliittisena kriisinä, jossa talouspoliittisesti siirrytään pääomien sääntelylle perustuneesta mallista vapaiden pääomaliikkeiden hallitsemaan järjestelmään. Tämä rahapolitiikan alueelta liikkeelle lähtevä poliittinen muutos heijastuu laajalle yhteiskunnan muihin politiikkalohkoihin ja poliittiseen keskusteluun. Tässä mielessä 1990-luvun al- kupuolen murrokselle lama voisikin olla talouskriisiä kokonaisvaltaisempi nimitys kuvaamaan myös sen poliittisia ja mentaalisia vaikutuksia.

Markkinavoimat ottivat vallan politiikalta ja astuivat sen ohi. Markkinoista tuli eliitin puhunnassa mekanismi, joka parantaa kansallisen säätelyn suojissa eläneen "sairaan" ja "pöhöttyneen" yhteiskunnan. Markkinoista on syntynyt uusi kurinpidollinen voima, johon koko yhteiskunnan on sopeuduttava. Markkinat tarkkailevat herkeämättä ja rankaisevat nopeasti niitä, jotka eivät sopeudu niiden toimintaan. Päättäjien puheessa on vahva moralisoiva sävy: talouskriisi ei ole seurausta poliittisesta siirtymästä markkinatalouteen, vaan ongelmat johtuvat ihmisten ja yhteiskunnan itsekurin pettämisestä. Talouskriisin syyllisyys paikantuu näin löysään elämään heittäytyneeseen rahvaaseen, ja eliitti pääsee vastuusta.

\section{Yksi mielenkiintoi-}

simpia Kantolan tulkinnoista koskee uusliberalismia. Hänen mukaansa uusliberaaliin hallintaan kätkeytyy ristiriita: samalla kun taloudelliset ja poliittiset vapaudet kasvavat, valtion ote kiristyy ja ulottuu yhä syvemmälle yksilöihin. Eliitille talouskriisi tulee ikään kuin "korkeimpien voimien lahjana". Kun kylmän sodan vastakkainasettelu ja Neuvostoliiton uhka poistuvat suomalaisesta politiikasta, myös eliitiltä katoaa hallinnan logiikka, johon nojata. Investointi- ja innovaatio-ohjelmien varaan on vaikea rakentaa koko kansaa kokoavaa myyttiä. Talouskriisi antaa uuden perustan, johon poliittinen hallinta voi nojata. Markkinat 
ottavat ulkopuolisen vaaran aseman. Kun aikaisemmin politiikkaa ja julkista keskustelua rajoitti itänaapurin valvova katse, nyt saman aseman ottavat kansainväliset markkinat, jotka vaativat kurinalaista käyttäytymistä eivätkä siedä veneenkeikuttamista.

Markkinakuri toimii näin sisäpoliittisen itsekurin ja kurinpidon välineenä.

Tätä kautta selittyy myös uusliberalismin voittokulku myös suomalaisessa yhteiskunnassa. Eliitti ei pidä toimiaan poliittisina ratkaisuina, vaan mieltää ne käytännön sanelemina vastauksina käytännöllisiin kysymyksin. Näin uusliberalismi ei näyttäydy ideologiana, vaan toimii puoluerajat ylittävänä pragmaattisena mentaalisena malli- na lujittaen eliitin konsensusta. Juuri tähän epäpoliittisuuteen perustuu uusliberalismin voima yhteiskunnan muuttamisessa. Pragmaattisesti itsensä perusteleva managerismi tarjoaa kansalliselle eliitille sillan ja turvaköyden yya-Suomesta EU-Suomeen.

\section{Anu Kantolan}

hahmottama kuva talouskriisin vaikutuksista suomalaiseen demokratiaan on karu: talouskriisi vahvisti talouden valtaa politiikassa. Epäpoliittiseen asioiden hoitoon nojaavat virkamiehet ja asiantuntijat saivat lisää määräysvaltaa politiikassa ja johtavat poliitikot omaksuivat "epäpoliittisen" managerieetoksen. Kun lama nyt alkaa useimmilla yhteiskuntaelämän aloilla olla ohi, voidaan kysyä, palasiko poli- tiikka politiikkaan? Vai onko niin, että Kantolan hyvin yhtenäiseksi kuvaamalla eliitillä on vielä projekteja, joiden toteuttamiseen tarvitaan managerieetosta ja kuria, jotka eivät siedä veneenkeikuttamista?

\section{Anu Kantolan}

tutkimuksen vahvuus on ennen kaikkea sen tarjoamassa uudessa tulkinnassa 1990-luvun alun talouskriisin poliittisesta hallinnasta. Tulkinnat ovat rohkeita, mutta perusteltuja ja ajatuksia herättäviä. Vanhasta leilistä löytyy todellakin uutta viiniä: tutkimus täydentää tärkeällä tavalla sitä kuvaa, mikä meillä on 1990luvun suuresta murroksesta.

Ilkka Ruostetsaari 